\title{
PENGARUH MODEL PEMBELAJARAN QUANTUM TEACHING TERHADAP KEMAMPUAN MENULIS PARAGRAF NARASI OEH SISWA KELAS X SMA KATOLIK BUDI MURNI 3 MEDAN
}

\author{
Friska Megawati Manalu', Asnita Hasibuan² \\ *1. Penulis \\ *2. Pembimbing \\ Program Studi Pendidikan Bahasa Indonesia,FakultasKeguruan dan Ilmu Pendidikan, Universitas Katolik \\ Santo Thomas, Jl. Setia Budi No. 479-F Tanjung Sari Medan - Kode Pos No. 20132, email- \\ audinamia@yahoo.co.id
}

Abstrak

Penelitian ini bertujuan untuk mengetahui pengaruh penggunaan model pembelajaran quantum teaching terhadap kemampuan menulis paragraf narasi. Penelitian ini dilakukan di SMA Katolik Budi Murni 3 Medan, pada semester ganjil tahun pembelajaran 2017/2018. Metode penelitian ini adalah metode eksperimen static group comparison dengan menggunakan dua kelas yaitu kelas kontrol dan kelas eksperimen. Populasi penelitian ini adalah semua siswa kelas X SMA Budi Murni 3 Medan dengan sampel berjumlah 70 . Instrumen yang digunakan untuk pengumpulan data adalah tes esai menulis paragraf narasi. Pengujian hipotesis dilakukan dengan menggunakan uji “ $t$ ”.'Hasil penelitian ini menunjukkan bahwa kemampuan siswa dalam menulis karangan narasi tanpa menggunakan model pembelajaran quantum teaching termasuk kategori cukup dengan nilai rata-rata 65,00 sedangkan dengan menggunakan model pembelajaran quantum teaching termasuk kategori baik dengan nilai rata-rata 77,57. Selanjutnya, dengan menggunakan uji t diperoleh $t$ hitung (to) sebesar 6,25, kemudian dikonsultasikan dengan tabel t pada taraf signifikan $\alpha=0,05$ dengan $\mathrm{dk}=68$ adalah 1,995 . Oleh karena $\mathrm{t}$ hitung yang diperoleh lebih besar dari t tabel yaitu 6,25> 1,995. Dengan demikian, terbukti bahwa hipotesis alternatif $\left(\mathrm{H}_{\mathrm{a}}\right)$ diterima dan dapat dinyatakan bahwa model pembelajaran quantum teaching berpengaruh terhadap kemampuan siswa dalam menulis paragraf narasi oleh siswa kelas X SMA Katolik Budi Murni 3 Medan tahun pelajaran 2017/2018. Dengan demikian bahwa model pembelajaran ini tepat digunakan dalam proses pembelajaran, khususnya dalam menulis paragraf narasi.

Kata Kunci: menulis paragraf narasi, quantum teaching.

\begin{abstract}
This researching to know the impact of Quantum Teaching earning model to narration pharagraf writing ability. This method was done at SMA Budi Murni 3 Medan, at odd semester in 2017/2018. This method is experiment method static group comparison by doing 2 classes, control and experiment class. This researching population is all the students of grade X SMA Budi Murni 3 Medan with 70 sample. The instrument which is used is narration pharagraf writing essay test. Hypothesis was done by doing " $t$ " test. The result of researching show that students ability in writing narration pharagraf without using Quantum Teaching including cathegory average score 65,00, while by using Quantum Teaching learning model including cathegory aerage score 77,57 . Next, by using " $t$ " test was got count $\mathrm{t}$ (to) 6,25. Then was consulted with $\mathrm{t}$ table at significant level $\alpha=0,05$ with $\mathrm{dk}=68$ is 1,995 . Because $t$ count which was got is bigger from t table 6,25>1,995. So, it is the proof that alternatif hypothesis $\left(\mathrm{H}_{\mathrm{a}}\right)$ is received and can be stated that Quantum Teaching learning model gives impact to students ability in writing narration pharagraf by students grade $\mathrm{X}$ SMA Budi Murni Medan in 2017/2018. So, this learning model can be used in learning process, especially in writing narration pharagraf.
\end{abstract}




\section{Key Words : narration pharagraf writing, quantum teaching.}

\section{PENDAHULUAN}

Keterampilan berbahasa meliputi empat jenis keterampilan yakni keterampilan menyimak, berbicara, membaca, dan menulis. Dari keempat keterampilan tersebut, menulis merupakan keterampilan yang paling sulit dan membosankan, karena bukan hanya makna dari isi tulisan tersebut yang diperhatikan pembaca tetapi dari segi bahasa yang digunakan penulis juga diperhatian. Pemilihan bahasa yang tepat sangat mempengaruhi pembaca terhadap tulisan yang ingin disampaikan penulis. Sehingga minat siswa untuk menuangkan ide-idenya dalam tulisan sangat kurang.

Pembelajaran bahasa dan sastra Indonesia dalam Kurikulum Tingkat Satuan Pendidikan (KTSP) bertujuan untuk meningkatkan kemampuan dan keterampilan siswa dalam berkomunikasi baik secara lisan maupun secara tertulis. Keterampilan menulis dipergunakan untuk berkomunikasi secara tidak langsung atau tidak secara tatap muka dengan orang lain. Keterampilan menulis ini tidak datang secara otomatis tetapi harus melalui latihan-latihan berkelanjutan dan praktik yang banyak dan teratur. Dengan demikian keterampilan menulis lebih banyak diperoleh dari pengalaman berulang-ulang melalui latihan di sekolah.

Menulis memegang peranan penting dalam kehidupan manusia, karena pengetahuan tidak terlepas dari menulis namun, kenyataannya kegiatan menulis di sekolah kurang diminati oleh siswa kurangnya minat dan motivasi siswa dalam proses pembelajaran menulis dapat menyebabkan rendahnya keterampilan menulis. Membangun minat tersebut sangatlah penting dilaksanakan. Belajar menulis akan lebih mudah jika seorang anak telah mencintai pelajaran tulis menulis terlebih dahulu.

Penguasaan kosakata yang masih kurang juga menghambat keberhasilan siswa dalam menulis. Kurangnya penguasaan kosakata menyebabkan siswa sering mengulang-ulang kata yang sama dalam satu paragraf dan mengalami kesulitan dalam memilih kata yang tepat. Siswa juga sering kesulitan dalam mengekspresikan pikiran atau gagasannya melalui bahasa yang baik dan benar, sehingga orang tersebut mengalami kesulitan dalam menulis.

Salah satu bentuk kegiatan menulis dalam pembelajaran bahasa Indonesia adalah menulis paragraf narasi. Paragraf narasi merupakan kompetensi menulis yang perlu diwujudkan oleh siswa SMA kelas $\mathrm{X}$ semester I karena materi ini terdapat dalam Standar Isi, Kurikulum Tingkat Satuan Pendidikan (KTSP), yakni pada Standar Kompetensi (4) Mengungkapkan informasi dalam berbagai bentuk paragraf (naratif, deskriptif. Ekspositif) dan Kompetensi Dasar (4.1) Menulis gagasan dengan menggunakan pola urutan waktu dan tempat dalam bentuk paragraf naratif (RPP).

Paragraf narasi adalah karangan atau cerita yang menyajikan suatu peristiwa atau kejadian serta bagaimana peristiwa itu berlangsung berdasarkan urutan waktu sehingga pembaca seolah-olah mengalami sendiri kejadian yang diceritakan itu. Peristiwa itu boleh benar-benar terjadi tapi boleh juga khayalan saja. Roman, novel, cerpen drama, biografi, dan kisah perjalanan termasuk jenis tulisan narasi.

Berdasarkan pengalaman penulis ketika melakukann Praktik Penelitian Lapangan (PPL) kemampuan menulis siswa kelas $\mathrm{X}$, khususnya dalam menulis paragraf masih rendah hal ini dikarenakan guru masih menggunakan metode konvensional, sehingga mempengaruhi minat siswa dalam menulis paragraf narasi. Penggunaan model dalam pembelajaran sangat diutamakan guna menimbulkan gairah belajar, motivasi belajar, merangsang siswa berperan aktif dalam proses pembelajaran. Guru diharapkan ketika mengajar di kelas dapat menciptakan kondisi lingkungan belajar yang dapat mendorong siswa belajar dan 
memberi kesempatan kepada siswa untuk berperan aktif dalam mengontruksi konsepkonsep yang dipelajarinya. Pembelajaran aktif adalah suatu pembelajaran yang mengajak peserta didik untuk belajar secara aktif.

Ada beberapa hal yang menyebabkan hasil yang belum maksimal pada siswa dalam menulis paragraf narasi. Yaitu: 1) Rendahnya minat siswa, 2) menulis merupakan kegiatan yang membosankan dan sulit, 3) pemilihan metode yang digunakan guru dalam penyampaian materi kurang tepat, sehingga suasana pembelajaran terasa membosankan, 4) tidak adanya kebiasaan menulis yang menyebabkan siswa kesulitan ketika mendapatkan pekerjaan untuk menulis

Berdasarkan permasalahan tersebut diperlukan model pembelajaran yang dapat mengatasi permasalahan yang dihadapi oleh guru dan siswa tersebut dalam proses pembelajaran menulis paragraf narasi. Salah satu model pembelajaran yang dapat digunakan adalah model pembelajaran Quantum Teaching.

Menurut Deporter (2010:34) Quantum Teaching adalah pendayagunaan interaksi baik di dalam dan di sekitar peristiwa belajar, yang mengubah kemampuan dan bakat alamiah siswa menjadi cahaya yang bermanfaat bagi dirinya sendiri dan orang lain. Pelaksanaan pembelajaran dengan menggunakan model Quantum Teaching ditekankan kepada siswa untuk dapat belajar efektif dengan menggunakan alam sebagai acuan berpikir sehingga siswa dapat memperoleh manfaat dan membangkitkan daya kreativita ssiswa. Model Quantum Teaching, siswa dapat mengkreasikan pikiran, suasana dan perasaan mereka sehingga mereka dapat memaksimalkan kemampuan dan prestasi. Hal tersebut didukung oleh hasil penelitian Dasmiati (2012) yang berjudul "Pengaruh Metode Quantum Teaching Terhadap Kemampuan Menulis Puisi Siswa Kelas X SMA Negeri 10 Medan Tahun Pembelajaran 2012/2013". Dari hasil penelitian tersebut diperoleh nilai rata-rata siswa meningkat setelah diterapkan metode Quantum Teaching yaitu 77,5, sedangkan sebelum diterapkan metode Quantum Teaching nilai rata-rata siswa hanya 68,125 . Hal tersebut menunjukkan bahwa metode Quantum Teaching dapat meningkatkan hasil pembelajaran.

Jika pada penelitian di atas metode Quantum Teaching diterapkan pada pembelajaran menulis puisi, maka pada penelitian ini peneliti menggunakan metode Quantum Teaching pada pembelajaran menulis paragraf narasi untuk mengetahui apakah terjadi pengaruh yang signifikan terhadap kemampuan menulis paragraf narasi.

Berdasarkan masalah di atas, peneliti tertarik melakukan penelitian dengan judul "Pengaruh Model Pembelajarann Quantum Teaching Terhadap Kemampuan Menulis Paragraf Narasi oleh Siswa Kelas X SMA Katolik Budi Murni 3 Medan Tahun Pembelajaran 2017/2018”.

\section{KAJIAN KEPUSTAKAAN}

Kerangka teoretis mencakup kajian terhadap teori-teori dan hasil-hasil penelitian yang relevan dengan masalah yang diteliti. Kemudian kerangka teori ini digunakan sebagai dasar pemikiran dalam penelitian yang dilakukan. Agar kerangka teoritis meyakinkan maka argumentasi yang disusun dalam membangun kerangka berpikir harus merupakan pilihan dari sejumlah teori yang dikuasai secara lengkap dengan perkembangan terbaru.

\section{Hakikat Model Pembelajaran}

Istarani (2011: 1) meyatakan, model pembelajaran adalah seluruh rangkaian penyajian materi ajar yang meliputi segala aspek sebelum, sedang, dan sesudah pembelajaran yang akan dilakukan guru serta segala fasilitas yang terkait yang digunakan secara langsung atau tidak langsung dalam proses belajar mengajar.

Rusman (2012: 134) pembelajaran pada hakikatnya merupakan suatu proses interaksi antara guru dengan siswa, baik interaksi secara langsung seperti kegiatan tatap muka 
maupun secara tidak langsung, yaitu dengan menggunakan berbagai media pembelajaran. Berdasarkan pendapat para ahli, dapat disimpulkan bahwa model pembelajaran adalah suatu konsep yang sudah dipersiapkan untuk proses interaksi antara guru dan siswa di dalam kelas.

\section{Hakikat Quantum Teaching}

Bobbi Deporter (2010: 32) menyatakan, Quantum Teaching adalah penggubahan belajar yang meriah, dengan segala nuansanya. Quantum Teaching juga menyertakan segala kaitan, interaksi, dan perbedaan yang memaksimalkan momen belajar. Quantum Teaching berfokus pada hubungan dinamis dalam lingkungan kelas, interaksi yang mendirikan landasan dan kerangka untuk belajar.

Quantum Teaching mencakup petunjuk spesifik untluk menciptakan lingkungan belajar yang efektif, merancang kurikulum, menyampaikan isi, dan memudahkan proses belajar. Quantum Teaching mempunyai kerangka rancangan belajar yang dikenal sebagai TANDUR: Tumbuhkan, Alami, Namai, Demonstrasi, Ulangi, dan Rayakan, (Deporter, 2004:8-9). Berikut ini akan dijelaskan satu persatu antara lain sebagai berikut:

1. Tumbuhkan

Tahap menumbuhkan minat siswa terhadap pembelajaran yang akan dilakukan. Melalui tahap ini, guru berusaha mengikutsertakan siswa dalam proses belajar. Motivasi yang kuat membuat siswa tertarik untuk mengikuti seluruh rangkaian. Tahap tumbuhkan bisa dilakukan untuk menggali permasalahan terkait dengan materi yang akan dipelajari, menampilkan suatu gambaran atau benda nyata, cerita pendek atau video

2. Alami

Alami merupakan tahap ketika guru menciptakan atau mendatangkan pengalaman yang dapat dimengerti semua siswa. Tahap ini memberikan kesempatan kepada siswa untuk mengembangkan keingintahuan siswa. Tahap alami bisa dilakukan dengan mengadapakan pengamatan

3. Namai

Tahap namai merupakan tahap memberikan kata kunci, konsep, model, rumus, atau strategi atas pengalaman yang telah diperoleh siswa. Dalam tahjap ini siswa dengan bantuan guru berusaha menemukan konsep atas pengalaman yang telah dilewati. Tahap penamaan memacu struktur kognitif siswa yang memberikan identitas, menguatkan, dan mendefenisikan atas apa pengetahuan awal dan keingintahuan siswa saat itu. Pemberian nama setelah pengalaman akan menjadi sesuatu lebih bermakna dan berkesan bagi siswa. Untuk membantu penamaan dapat digunakan susunan gambar, warna alat bantu, kertas tulis, dan poster dinding

4. Demonstrasi

Tahap demonstrasi memberikan kesempatan untuk menerapkan pengetahuan ke dalam pembelajaran yang lain dan ke dalam kehidupan mereka. Tahap ini menyediakan kesempatan kepada siswa untuk menjukkan apa yang meraka ketahui. Tahap demonstrasi bisa dilakukan dengan penyajian di depan kelas, permainan, menjawab pertanyaan, dan menunjukkan hasil pekerjaan.

5. Ulangi

Pengulangan akan memperkuat koneksi saraf sehingga menguatkan struktur kognitif siswa. Semakin sering dilakukan pengulangan, pengetahuan akan semakin mendalam. Bisa dilakukan dengan menegaskan kembali pokok materi pelajaran, memberi kesempatan siswa untuk mengulang pelajaran dengan teman lain atau melalui latihan soal.

6. Rayakan

Rayakan merupakan wujud pengakuan untuk menyelesaikan partisipasi dan menyelesaikan partisipasi dan memperoleh 
keterampilan dalam ilmu pengetahuan. Bisa dilakukan dengan pujian, tepuk tangan, dan bernyanyi bersama

\section{Hakikat Kemampuan Menulis Paragraf Narasi}

Tarigan (2013: 3) menyatakan menulis merupakan suatu keterampilan berbahasa yang dipergunakan untuk berkomunikasi secara tidak langsung, tidak secara tatap muka dengan orang lain. Semi (2007: 14) juga menyatakan menulis merupakan suatu proses kreatif memindahkan gagasan ke dalam lambang-lambang tulisan.

Dalman (2014: 3) menyatakan menulis merupakan suatu kegiatan komunikasi berupa penyampaian pesan (informasi) secara tertulis kepada pihak lain dengan menggunakan bahasa tulis sebagai alat atau medianya. Berdasarkan pendapat para ahli dapat disimpulkan bahwa menulis adalah kesanggupan menggunakan bahasa dalam kegiatan komunikasi secara tidak langsung untuk menyampaikan pesan (informasi) kepada orang lain.

\section{Pengertian Paragraf}

Kosasih (2003: 22) paragraf merupakan bagian dari karangan (tertulis) atau bagian dari turunan (kalau lisan). Sebuah paragraf ditandai oleh suatu kesatuan gagasan yang lebih tinggi atau lebih luas daripada kalimat. Oleh karena itu, paragraf umumnya terdiri dari sejumlah kalimat. Kalimat-kalimat itu saling bertalian untuk mengungkapkan sebuah gagasan tertentu. Di dalam KBBI (Kamus Besar Bahasa Indonesia) paragraf didefinisikan sebagai bagian bab dalan suatu karangan (biasanya mengandung satu ide pokok dan penulisannya dimulai dengan garis baru).

Semi (2007: 86) menyatakan yang dimaksud dengan paragraf ialah seperangkat kalimat yang mengacu kepada satu topik. Dalam setiap tulisan ditemui rangkaian paragraf, yang semuanya menunjang atau mengacu kepada topik tulisan. Artinya, setiap paragraf yang ditampilkan hendaknya mempunyai kaitan dengan pembahasan topik tulisan.
Berdasarkan pendapat para ahli di atas dapat disimpulkan bahwa paragraf adalah

kumpulan kalimat yang berhubungan antara yang satu dengan yang lain dan di dalamnya terdapat ide-ide dari penulis.

\section{Pengertian Narasi}

Dalman (2014: 55) menyatakan narasi adalah cerita. Cerita ini berdasarkan pada urutan-urutan suatu atau (serangkaian) kejadian atau peristiwa. Keraf (dalam Dalman, 2014: 106) menyatakan karangan narasi adalah merupakan suatu bentuk karangan yang sasaran utamanya adalah tindak tanduk yang dijalin dan dirangkai menjadi sebuah peristiwa yang terjadi dalam suatu kesatuan waktu.

Berdasarkan pendapat di atas dapat disimpulkan bahwa narasi adalah cerita yang mengisahkan manusia atau menceritakan sebuah pengalaman manusia yang di dalamnya terdapat tokoh yang berperan dan urutan waktu.

\section{Paragraf Narasi}

Kosasih (2003: 28) menyatakan paragraf narasi adalah paragraf yang menceritakan suatu peristiwa atau kejadian sedemikian rupa sehingga pembaca seolah-olah mengalami sendiri kejadian yang diceritakan itu. Dalman (2014: 105) menyatakan paragraf narasi adalah suatu bentuk tulisan yang berusaha menciptakan, mengisahkan, dan merangkaikan tindak tanduk perbuatan manusia dalam sebuah peristiwa secara kronologis atau berlangsung dalam suatu kesatuan waktu.

Berdasarkan pendapat di atas, dapat disimpulkan bahwa paragraf narasi adalah paragraf yang menceritakan suatu kejadian berdasarkan urutan waktu hingga pembaca seolah-olah melihat langsung dan mengalami sendiri kejadian tersebut.

HASIL PENELITIAN YANG RELEVAN 1.Dasmiati (2012) dalam penelitiannya yang berjudul Pengaruh Model Quantum Teaching Terhadap Kemampuan Menulis Puisi Siswa Kelas X SMA Negeri 10 Medan Tahun Pelajaran 2012/2013 Peningkatan Keterampilan Menulis Puisi Hasil penelitian tentang pengaruh model Quantum Teaching 
terhadap kelas X SMA Negeri 10 Medan dengan model pembelajaran konvensional tergolong cukup, dengan nilai tertinggi 85 dan nilai terendah 55 , nilai rata-rata 68,125 dan standart deviasi 6,93 kemampuan menulis puisi siswa kelas X SMA Negeri 10 Medan Tahun Pembelajaran 2012/2013 dengan model Quantum Teaching tergolong baik dengan nilai tertinggi 90 dan nilai terendah 60 , nilai rat-rata 77,5 dan standart deviasi 7,93

2.Fransiska Sitohang (2014) dalam penelitiannya yang berjudul Pengaruh Model Quantum Teaching Terhadap Kemampuan Menulis Paragraf Model Quantum Teaching Terhadap Kemampuan Menulis Paragraf Deskripsi Siswa Kelas VIII SMP ST. Yoseph Tanjung Selamat Medan Tahun Pelajaran 2014/2015

Hasil penelitian dengan menggunakan model Quantum Teaching lebih baik dari pada hasil belajar yang dibimbing dengan model konvensional. Data penelitian ini dianalisis dengan statistik "t" karena $t_{\text {hitung }}$ lebih besar dari pada $t_{\text {tabel }}$ yaitu, maka $\mathrm{Ha}$ diterima dan Ho ditolak. Hal itu berarti model Quantum Teching berpengaruh dalam meningkatkan kemampuan menulis paragraf deskripsi siswa kelas VIII SMP St. Yoseph Tanjung Selamat Medan Tahun Pelajaran 2014/2015.

3.Ria Liniarti (2014) Roberto (2010) dalam penelitiannya yang berjudul Pengaruh Model Pembelajaran Quantum Teaching Terhadap hasil belajar IPS di SMP Negeri 178 Jakarta Tahun Pelajaran 2014/2015 Hasil penelitian menunjukkan bahwa terdapat pengaruh yang signifikan penggunaan model pembelajaran Quantum Teaching terhadap hasil belajar biologi dengan rata-rata hasil belajar eksperimen sebesar 80,02 dan kelas kontrol sebesar 75, 07 .

\section{KERANGKA BERPIKIR}

Berdasarkan kerangka teoritis penelitian ini, maka dapat diketahui bahwa penelitian ini terdiri dari dua variabel, yaitu variabel bebas dan variabel terikat. Variabel bebas dalam penelitian ini adalah model pembelajaran Quantum Teaching dan variabel terikatnya adalah kemampuan menulis paragraf narasi.

Model pembelajaran Quantum Teaching merupakan pembelajaran yang dapat dilakukan untuk menciptakan proses belajar yang lebih menyenangkan dan selalu dikaitkan dengan lingkungan kelas sehingga memudahkan siswa menuliskan suatu pemikiran yang didapatkan.

Berdasarkan penjelasan mengenai paragraf narasi yang dipaparkan dalam kerangka teoritis, paragraf narasi merupakan paragraf yang menceritakan suatu peristiwa atau kejadian sedemikian rupa sehinga pembaca seoalah-olah mengalami sendiri kejadian yang diceritakan itu. Kemampuan menulis paragraf narasi merupakan salah satu kompetensi dasar yang harus dicapai oleh siswa SMA kelas $\mathrm{X}$ dalam pembelajaran bahasa Indonesia. Akan tetapi pada kenyataannya, siswa masih kurang mampu menulis paragraf narasi.

Agar siswa lebih mampu menulis paragraf narasi dengan tepat, model pembelajaran yang tepat dan menarik diperlukan untuk membantu siswa memperoleh ide. Salah satu model pembelajaranyang tepat dan menarik tersebut adalah model pembelajaran Quantum Teaching. Model ini melibatkan siswa secara aktif dalam proses pembelajaran karena dalam model pembelajaran ini, guru mengajak siswa untuk melihat dan mengamati lingkungan sekolah dan melalui pengataman siswa mengenai lingkungann sekolah dapat memudahkan siswa menuangkan ide-ide nya ke dalam tulisan. Dengan demikian, model pembelajaran Quantum Teaching diharapkan mampu memudahkan siswa dalam menulis paragraf narasi.

\section{HIPOTESIS}

Hipotesis merupakan jawaban sementara terhadap rumusan masalah penelitian, di mana rumusan masalah penelitian telah dinyatakan dalam bentuk kalimat 
pertanyaan. Jadi, yang menjadi hipotesis penelitian ini adanya Pengaruh Model Pembelajaran Quantum Teaching Terhadap Kemampuan Menulis Paragraf Narasi Oleh Siswa Kelas X SMA Katolik Budi Murni 3 Medan Tahun Pelajaran 2017/2018.

\section{METODOLOGI PENELITIAN}

Metode penelitian adalah cara ilmiah atau (rasional, empiris, dan sistematis) yang digunakan oleh pelaku suatu disiplin ilmu untuk melakukan penelitian. Rasional berarti kegiatan penelitian tersebut dilakukan dengan cara - cara yang masuk akal, sehinga terjangkau oleh penalaran manusia. Empiris berarti cara yang dilakukan itu dapat diamati oleh indera manusia, sehingga orang lain pun dapat mengamatinya. Sistematis berarti proses yang dilakukan dalam penelitian itu menggunakan langkah - langkah tertentu bersifat logis.

Sujerweni (2014 :5) Metode penelitian berhubungan erat dengan prosedur, teknik, alat, serta desain penelitian yang digunakan. Dalam metode penelitian menggambarkan rancangan penelitian yang meliputi prosedur atau langkah-langkah yang harus ditempuh, waktu penelitian, sumber data, serta dengan cara apa data tersebut diperoleh dan diolah atau dianalisis.

Dalam penelitian ini metode yang digunakan adalah metode kuantitatif. Penelitian kuantitatif adalah jenis penelitian yang menghasilkan penemuan-penemuan yang dapat dicapai (diperoleh) dengan menggunakan prosedur-prosedur statistik atau cara-cara lain dari kuantifikasi (pengukuran). Pendekatan kuantitatif memusatkan perhatian pada gejala-gejala yang mempunyai karakteristik tertentu di dalam kehidupan manusia yang dinamakannya sebagai variabel. Dalam pendekatan kuantitatif hakikat hubungan di antara variabel-variabel dianalisis dengan menggunakan teori yang obyektif.

Berdasarkan tujuan penelitian ini metode yang dipergunakan adalah metode kuantitatif dengan tujuan ingin mengetahui bagaimana Pengaruh Model Pembelajaran Quantum Teaching Terhadap Kemampuan Menulis Paragraf Narasi Oleh Siswa Kelas X SMA Katolik Budi Murni 3 Medan Tahun Pelajaran 2017/2018 dan alasan digunakannya metode ini karena metode ini bermanfaat membangkitkan daya kreativitas siswa dan menciptakan susasana belajar yang menyenangkan sehingga memudahkan siswa menulis paragraf narasi

\section{Tempat, Kegiatan dan waktu penelitian Tempat Penelitian}

Penelitian ini dilakukan di SMA Katolik Budi Murni 3 Medan tahun pembelajran 2017/2018.

\section{Waktu Penelitian}

Penelitian ini dilaksanakan pada semester ganjil 2017-2018.

\section{Rancangan atau Desain Penelitian}

Noor (2011: 108) menyatakan desain penelitian diklasifikasikan sebagai rencana dan struktur investigasi yang dibuat sedemikian rupa sehingga diperoleh jawaban atas pertanyaan penelitian. Rencana penelitian mencakup garis besar dari apa yang akan dilakukan seorang peneliti mulai dari penulisan hipotesis serta implikasi operasionalnya hingga ke analisis akhir data.

Desain penelitian yang digunakan peneliti adalah Static Group Comparison Design (perbandingan kelompok statis). Noor (2011: 116) menyatakan desain penelitian Static Group Comparison, data kelompok dibagi menjadi dua: separuh diberi pelatihan (eksperimen) dan separuh lagi tidak diberi pelatihan (kelompok kontrol). Desain penelitian ini hanya dilakukan pos-test yang kemudian dibandingkan untuk menentukan pengaruh treatment.

\section{Jenis dan sumber Data}

Data adalah keterangan yang masih belum dioalah menjadi sebuah informasi. Noor (2011: 138) menyatakan bahwa data (datum) adalah sesuatu yang diketahui. Sekarang diartikan sebagai informasi yang 
diterimanya tentang suatu kenyataan atau fenomena empiris, wujudnya dapat berupa seperangkat ukuran (kuantitatif, berupa angka-angka atau berupa ungkapan katakata (verbalize) atau kualitatif. Jenis data yang digunakan dalam penelitian ini data kuantitatif yaitu hasil atau skor yang diperoleh siswa dalam menulis paragraf narasi dan Sumber data adalah subjek dari mana asal data penelitian itu diperoleh. Dalam penelitian ini sumber data yang digunakan oleh penulis adalah data yang langsung diperoleh dari subjek penelitian (data primer) yaitu siswa kelas X SMA Katolik Budi Murni 3 Medan dengan jumlah 70 orang untuk mendapatkan hasil belajar siswa dalam menulis paragraf narasi.

\section{Teknik dan Alat Pengumpulan Data}

Teknik pengumpulan data merupakan cara yang dilakukan peneliti untuk mengungkap atau menjaring informasi kuantitatif dari responden sesuai lingkup penelitian. Teknik pengumpulan data juga diartikan sebagai cara mengumpulkan data yang dibutuhkan untuk menjawab rumusan masalah penelitian. Penggunaan teknik dan alat pengumpulan data yang tepat memungkinkan diperolehnya data yang objektif.

Dalam penelitian ini, teknik pengumpulan data dilakukan dengan memberikan tes akhir yang disebut post-test dan alat pengumpul datanya adalah tes tertulis dengan menulis paragraf narasi.

\section{Instrumen Penelitian}

Arikunto (2016: 192) instrumen penelitian adalah alat atau fasilitas yang digunakan peneliti dalam mengumpulkan data agar pekerjaannya lebih mudah dan hasilnya lebih baik, dalam arti lebih cermat, lengkap, dan sistematis sehingga lebih mudah diolah. Untuk mengetahui pengaruh model pembelajaan Quantum Teaching terhadap kemampuan menulis paragraf narasi, peneliti menggunakan instrumen tes esai.

\section{Teknik Pengolahan dan Analisis Data}

Setelah data dikumpulkan, data perlu diolah atau dianalisis untuk mendapatkan kesimpulan mengenai hal yang diteliti. Penelitian ini merupakan penelitian kuantitatif, oleh sebab itu data yang digunakan yaitu analisis statistik, dimana peneliti berurusan dengan data yang berupa angka-angka. Sudijono (2008: 315) menyatakan, langkah-langkah analisis tersebut dilakukan dengan cara:

1. Mengoreksi atau memeriksa kertas jawaban siswa

2. Mentabulasi skor post-test

3. Mencari mean hasil post-test

\section{HASIL PENELITIAN DAN PEMBAHASAN}

Penelitian ini merupakan penelitian eksperimen dengan melibatkan dua kelompok. Kelompok pertama adalah kontrol $\left(\mathrm{X}_{1}\right)$ tanpa menggunakan model pembelajaran Quantum Teaching. Kelompok ke dua adalah kelompok eksperimen $\left(\mathrm{X}_{2}\right)$ dengan menggunakan model pembelajaran Quantum Teaching. Data dikumpulkan dengan menggunakan tes essai menulis paragraf narasi .

\section{Pengolahan Data}

Setelah mengetahui kelas kontrol dan kelas eksperimen, selanjutnya, akan dibuat tabel distribusi frekuensi. Hal ini dilakukan untuk mengetahui rata-rata (mean), standar deviasi (SD), dan standar error (SE) dari data kontrol dan eksperimen yang diberikan kepada siswa melalui perhitungan sebagaimana diuraikan di bawah ini.

\section{Data Kelas Eksperimen}

Berdasarkan hasil tes kemampuan memerankan tokoh drama pada siswa yang dilakukan peneliti terhadap 35 siswa kelas X SMA Katolik Budi Murni 3 Medan

\section{Pengujian Persyaratan Analisis}

Statistik yang digunakan untuk melakukan uji data yaitu statistik komparasi dengan menggunakan uji "t". Analisis yang dilakukan harus dengan persyaratan bahwa yang diteliti adalah dari populasi yang berdistribusi normal dan variansi dari 
kelompok yang membentuk sampel homogen. Dengan demikian normalitas dan homogenitas merupakan persyaratan dasar bagi berlakunya komparasi.

\section{Uji Normalitas Data Kelas Eksperimen}

Uji normalitas bertujuan untuk mengetahui normal atau tidaknya data setiap variabel peneliti. Uji normalitas data yang digunakan dalam penelitian ini ialah dengan uji normalitas Lilliefors. Sundayana, ( 2015: 83) menyatakan bahwa data berdistribusi normal jika $\mathrm{L}_{\text {hitung }}<\mathrm{L}_{\text {tabel }}$. Berdasarkan tabel tersebut, diperoleh harga $\mathrm{L}_{\text {hitung }}=0,9$ sedangkan dari daftar nilai kritis untuk uji Lilliefors pada taraf signifikan $\alpha=0,05$ dan $\mathrm{n}=35 \mathrm{~L}_{\text {tabel }}=0,14$. Dengan demikian diperoleh $\mathrm{L}_{\text {hitung }}<\mathrm{L}_{\text {tabel }}$ atau $0,9<0,114$ ini membuktikan bahwa data nilai kelas eksperimen dengan menggunakan model quatum teaching berdistribusi normal.

\section{Uji Hipotesis}

Berdasarkan pengujian normalitas dan homogenitas dari kelompok pre-test dan post-test di atas, maka hasilnya menunjukkan bahwa persyaratan analisis dalam penelitian ini berdistribusi normal dan bervariansi populasi homogen. Hal ini menunjukkan bahwa persyaratan analisis dalam penelitian ini terpenuhi, sehingga dapat dilanjutkan pada pengujian hipotesis dengan uji "t" (Sudijono 2008:327) Setelah $t_{o}$ diketahui, selanjutnya dikonsultasikan dengan tabel $\mathrm{t}$ pada taraf signifikasi 0,05 dengan harga $\mathrm{t}_{\text {tabel }}$ pada $\mathrm{dk}=\left(\mathrm{n}_{1}+\mathrm{n}_{2}\right)-2=$ 68, maka diperoleh tafar signifikan $0,05=$ 1,995 dengan nilai $t_{\text {hitung dibandingkan }}$ dengan $t_{\text {tabel }}, \quad t_{\text {hitung }}>t_{\text {tabel }} \quad(6,25>1,995)$. Sebagai kriteria hipotesis diterima atau ditolak. Maka, $\mathrm{H}_{0}$ ditolak dan $\mathrm{H}_{\mathrm{a}}$ diterima. Hal ini membuktikan bahwa model pembelajaran quantum teaching berpengaruh dalam kemampuan menulis paragraf narasi pada siswa.

\section{Pembahasan Hasil Temuan}

Berdasarkan hasil penelitian, maka diperoleh temuan penelitian sebagai berikut:
1. Kemampuan siswa dalam menulis paragraf narasi dengan menggunakan quantum teaching menunjukkan nilai rata-rata 77,57 termasuk dalam kategori baik.

2. Kemampuan siswa dalam menulis paragraf narasi tanpa menggunakan quantum teaching menunjukkan nilai rata-rata 65 termasuk dalam kategori cukup.

3. Berdasarkan perhitungan dengan uji " $\mathrm{t}$ " diperoleh nilai $t_{o}=6,25$ kemudian dikonsultasikan dengan tabel $\mathrm{t}$ pada taraf signifikan 0,5\% dengan $\mathrm{dk} 68$ adalah 1,995. Oleh karena $t_{o}$ yang diperoleh lebih besar dari $t_{\text {tabel }}$ yaitu 6,25>1,995 maka hipotesis nihil (Ho) ditolak dan hipotesis alternatif (Ha) diterima. Hal ini membuktikan bahwa media pembelajaran berupa quatum teaching lebih efektif daripada tanpa menggunakan quatum teaching.

\section{Pembahasan Hasil Temuan Penelitian}

Setelah melakukan prosedur penelitian, tanpa menggunakan quantum teaching yang dilakukan pada siswa kelas X SMA Katolik Budi Murni 3 dalam menulis paragraf narasi masih dalam kategori cukup. Hal ini terbukti dari hasil penelitian yang menunjukkan bahwa kemampuan siswa dalam menulis paragraf narasi yang dilakukan pada pretest masih dalam kategori cukup. Dalam penilaiannya terbagi dalam lima kategori, yaitu kategori sangat baik sebanyak 3 siswa atau $8,57 \%$, kategori baik sebanyak 9 siswa atau $25,73 \%$, kategori cukup sebanyak 15 siswa atau $42,85 \%$, dan kategori kurang sebanyak 8 siswa atau 22,85\%. Dari identifikasi kelas kontrol yang paling banyak adalah kategori cukup. Oleh karena itu, perlu diketahui bahwa nilai yang diperoleh siswa disebabkan minimnya penggunaan media pembelajaran yang diberikan oleh guru. Dengan adanya media pembelajaran, siswa akan terbantu untuk memperoleh informasi serta pengetahuan siswa akan semakin bertambah karena media pembelajaran yang diberikan peneliti 
sangat membantu sekali untuk memanfaatkan indera para siswa. Dengan adanya model pembelajaran yang diterapkan maka akan memudahkan siswa untuk memahami suatu materi pembelajaran. Dalam hal ini bahwa media pembelajaran yang ditampilkan oleh peneliti sangat membantu siswa untuk lebih kreatif dalam pembelajaran serta mampu untuk menuangkan ise kreatif khususnya dalam menulis paragraf narasi .

\section{SIMPULAN， KETERBATASAN，DAN SARAN}

Berdasarkan hasil penelitian yang telah diuraikan di atas, maka dapat disimpulkan sebagai berikut:

1. Nilai rata-rata kemampuan menulis paragraf narasi siswa kelas X SMA Katolik Budi Murni 3 Medan tahun pembelajaran 2017/2018 tanpa menggunakan model pembelajaran quantum teaching adalah 65 berada dalam kategori cukup.

2. Nilai rata-rata kemampuan menulis paragraf narasi siswa kelas X SMA Katolik Budi Muni 3 Medan tahun pembelajaran 2017/2018 dengan menggunakan model pembelajaran quantum teaching adalah 77,57 berada dalam kategori baik.

3. Hasil belajar siswa dengan menggunakan model quantum teaching berpengaruh signifikan terhadap pembelajaran menulis karangan narasi. Berdasarkan hasil uji hipotesis maka dapat disimpulkan bahwa $t_{\text {hitung }}$ diperoleh lebih besar dari $t_{\text {tabel }}$ yaitu 6,25 $>1,995$ artinya hipotesis nihil $\left(\mathrm{H}_{0}\right)$ ditolak dan hipotesis alternatif $\left(\mathrm{H}_{\mathrm{a}}\right)$ diterima.

\section{Keterbatasan Penelitian}

Dalam penelitian yang sudah dilakasanakan, tentunya mempunyai banyak keterbatasan. Keterbatasan-keterbatasan yang penulis temukan saat penelitian adalah.

1. Ada beberapa siswa yang tidak aktif pada saat proses pembelajaran berlangsung, sehingga peneliti harus memperingatkan siswa untuk aktif selama proses pembelajaran berlangsung

2.Pada saat pembelajaran berlangsung, remot proyektor berpindah-pindah ke kelas yang lain sehingga siswa terpaksa mencari remot ke kelas lain dan sudah pasti ini mangganggu proses pembelajaran.

Namun, hal-hal yang menjadi keterbatasan penelitian di atas tidak menjadi hambatan bagi peneliti dalam proses penelitian, sehingga penelitian yang dilakukan peneliti dapat berjalan dengan baik.

\section{Saran}

Berdasarkan pembahasan dan kesimpulan dari hasil penelitian di atas, maka penulis memberikan saran sebagai berikut.

1. Guru, dapat menerapakan model pembelajaran quantum teaching untuk meningkatkan kualitas siswa dalam menulis paragraf narasi.

2. Kepada Siswa disarankan agar lebih efektif mengikuti kegiatan pembelajaran yang selama ini dilaksanakan, serta lebih aktif berdiskusi yang nantinya akan menambah wawasan dan ilmu pengetahuan

3. kepada calon-calon peneliti selanjutnya agar dapat melaksanakan penelitian lebih lanjut, untuk mengetahui besarnya partisipasi model uantum teaching untuk mempengaruhi kemampuan siswa menulis paragraf narasi.

4. Hasil penelitian tentang kemampuan menulis paragraf narasi diharapkan mampu menjadi pegangan bagi pelaku dalam bidang pendidikan.

5. Kepala sekolah sebagai tempat atau wadah mendidik agar lebih memperhatikan sarana dan sistem pengajaran guna meningkatkan mutu pengajaran khususnya bidang mata pelajaran bahasa dan sastra Indonesia.

DAFTAR KEPUSTAKAAN

Arikunto, Suharsimi. 2016. Prosedur Penelitian. Jakarta: Rineka Cipta. 
Azwar, Saifuddin. 2013. Metode Penelitian. Yogyakarta: Pustaka Pelajar.

Dalman. 2012. Keterampilan Menulis. Jakarta: Rajawali Pers.

Dasmiati. 2013. Pengaruh Model Quantum Teaching Terhadap Kemampuan Menulis Puisi Siswa Kelas X SMA Negeri 10 Medan.

Deporter, Bobbi. 2010. Quantum Teaching. Bandung: Kaifa.

Departemen Pendidikan Nasional. 2012. Kamus Besar Bahasa Indonesia (Edisi Kelima). Jakarta: Balai Pustaka.

Istarani. 2011. 58 Model Pembelajaran Inovatif. Medan: Media Persada.

Kosasih. 2003. Ketatabahasaan dan Kesustraan. Bandung: CV. Yrama Widya.

Liniarti, Ria. 2015. Pengaruh Penggunaan Model Pembelajaran Quantum Teaching Terhadap Hasil Belajar IPS di SMP Negeri 178 Jakarta. Diakses tanggal 10 April 2017.

Noor, Juliansyah. 2011. Metodologi Penelitian. Jakarta: Prenadamedia Group.

Nurgiyantoro, Burhan. 2014. Penilaian Pembelajaran Bahasa. Yogyakarta: Anggota IKAPI.

Semi, Atar. 2007. Dasar-dasar Keterampilan Menulis. Bandung: Angkasa

Shoimin, Aris. 2014. 68 Model Pembelajaran Inovatif Dalam Kurikulum 2013. Yogyakarta: Ar Ruzz Media.

Sitohang, Fransiska. 2015. Pengaruh Model Quantum Teaching Terhadap Kemampuan Menulis Paragraf Deskripsi Siswa Kelas VII SMP ST. Yoseph Tanjung Selamat Medan Tahun Pelajaran 2014/2015.
Sudijono. 2008. Pengantar Statistik Pendidikan. Jakarta: Rineka Cipta.

Sudjana. 2005. Metode Statistika. Bandung: Tarsito.

Sugiyono. 2012. Metode Penelitian Kuantitatif Kualitatif dan $R \& D$. Bandung: Alfabeta.

Tarigan, Henry Guntur. 2013. Menulis Sebagai Suatu Keterampilan Berbahasa. Bandung : Percetakan Angkasa. 